\title{
ОРГАНИЧЕСКОЕ ВЕЩЕСТВО В ГИДРОТЕРМАЛЬНЫХ СИСТЕМАХ ДАЛЬНЕГО ВОСТОКА РАЗНЫХ ТИПОВ И ОБСТАНОВКИ
}

\author{
Потурай Валерий Алексеевич, \\ poturay85@yandex.ru \\ Институт комплексного анализа региональных проблем ДВО РАН, \\ Россия, 679000, г. Биробиджан, ул. Шолом-Алейхема, 4.
}

Актуальность исследования определяется необходимостью изучения состава органического вещества в обитаемой и необитае-
мой областях гидротермальных систем разных типов. Органические соединения в термальных водах, населенных сообществ-
ми термофилов и лишенных жизни (стерильная пароводяная смесь), формируют, соответственно, частный биотический и аби-
отический круговорот органического вещества. Учитывая слабую изученность данных процессов в дальневосточных гидротер-
мальных системах, изучение состава и генезиса органического вещества в них представляется важным для выявления законо-
мерностей превращения вещества в ходе круговорота. Кроме этого, данные по органическим веществам в обитаемой и необи-
таемой областях гидротермальных систем имеют значение для региональной экологии и бальнеологии, поскольку термальные
воды используются для лечения людей в санаториях и бальнеолечебницах. Цель исследования: провести сравнительный анализ состава органического вещества в разных по типу и обстановкам гидротермальных системах Дальнего Востока и выявить наиболее характерные органические соединения, формирующие частные биотический и абиотический круговороты.

Объекты: гидротермальные системы континентальной части юга Дальнего Востока (термальная вода из неглубоких скважин Кульдурского, Анненского и Тумнинского геотермальных месторождений) и полуострова Камчатки (стерильная пароводяная смесь, высокотемпературный раствор и горячие источники Мутновского и Паратунского геотермальных районов).

Методы: полевые маршруты, твердофазная экстракция, капиллярная газовая хроматомасс-спектрометрия, расчет индексов нечетности, картографический метод.

Результаты. Установлено 210 органических соединений, принадлежащих 22 гомологическим рядам. Характерной чертой всех изученных горячих вод и флюида является преобладание простых углеводородов (предельных и ароматических). В основном только эти компоненты формируют абиогенный круговорот органического вещества во флюиде из необитаемой зоны. В воде горячих источников Камчатки и из неглубоких скважин континентальных термальных полей, кроме простых углеводородов, широко распространены биогенные карбоновые кислоты и их эфиры, а в континентальных термальных водах еще и биогенные альдегиды и терпены. Эти соединения в основном формируют биогенный круговорот органического вещества в гидротермальных системах. Отличием термальных вод и флюида п-ова Камчатка от континентальных терм является более широкое распространение предельных и ароматических углеводородов, спиртов, кетонов, а также наличие изопренов, изоалкенов и циклоалканов. Наиболее разнообразный состав органического вещества наблюдается в термальных водах на континенте. Здесь, наряду с компонентами, найденными в термальных водах Камчатки, присутствуют алкены, диэтоксиалканы, диоксаалканы, азотсодержащие и хлорароматические углеводороды и хиноны.

\section{Ключевые слова:}

Термальная вода, высокотемпературный раствор, пароводяная смесь, органическое вещество, биотический и абиотический круговороты.

\section{Введение}

Территория Российского Дальнего Востока характеризуется многочисленными проявлениями термальных вод с температурой до $100{ }^{\circ} \mathrm{C}$ и выше. Их формирование обусловлено как нормальным геотермическим режимом, при котором воды нагреваются за счет термоградиента в результате циркуляции в глубокие области земной коры (континентальная часть юга Дальнего Востока), так и магматогенным геотермическим режимом, который поддерживается близким расположением магматического очага к поверхности (полуостров Камчатка). В первом случае термальные воды обладают сравнительно невысокой температурой (ниже $80{ }^{\circ} \mathrm{C}$ ), что позволяет здесь жить и развиваться различным термофильным комплексам $[1,2]$. Наиболее мощные геотермальные месторождения здесь Кульдурские, Анненские и Тумнинские термальные воды. Во втором случае гидротермальные системы имеют очень высокую температуру воды (выше $80{ }^{\circ} \mathrm{C}$ ), и их приповерхностные области насе- лены сообществами гипертермофилов, обитающих при температуре от 80 до $110-120^{\circ} \mathrm{C}[3,4]$, однако более глубокие области остаются стерильными (безжизненными), вследствие экстремально высоких температур (выше $110-120{ }^{\circ} \mathrm{C}$ ) и давления (рис. 1). Одни из наиболее мощных и высокотемпературных гидротермальных систем здесь - Мутновский и Паратунский геотермальные районы.

Органическое вещество $(\mathrm{OB})$ в обитаемой области гидротермальных экосистем, как на континенте, так и на п-ове Камчатка, большей своей частью продуцируется живыми организмами и формирует частный биотический круговорот ОВ, который поддерживается через деструкцию микроорганизмов с последующим вовлечением биогенного ОВ в процессы жизнедеятельности. Некоторая часть ОВ может поступать в термальные воды в результате ре-синтеза экстрагированных из вмещающих пород органических остатков. В необитаемой области гидротермальных систем биотический круговорот OВ маловероятен, поскольку жизни в таких обла- 
стях нет. Вследствие этого органические соединения в этих зонах составляют частный абиотический круговорот ОВ, происходящий без участия живых организмов.

Исследования в области органической гидрогеохимии направлены в основном на изучение органических соединений в подводных океанических гидротермальных системах. Здесь установлены разнообразные органические компоненты, в основном простые углеводороды (УВ), имеющие абиогенный генезис [5-15, и др.]. Кроме этого, химический синтез УВ рассматривается и в лабораторных экспериментах, моделирующих гидротермальные процессы и верхнюю мантию земной коры [12, 16-21, и др.]. Исследования ОВ в континентальных гидротермальных системах ДВ и высокотемпературных водах полуострова Камчатка немногочисленны. В основном они касаются изучения УВ нефтепроявлений кальдеры Узон [22-25], высоколетучих органических соединений и аминокислот Мутновского и Паужетского геотермальных районов [26, 27]. Эти гидротермаль- ные системы подвергались также и изучению различных аспектов геологии, химического состава и условий формирования термальных вод [28-33, и др.]. Кроме этого, нами уже проводилось изучение OB в гидротермальных системах на континенте ДВ [34-37] и в Мутновском геотермальном районе (пов Камчатка) [38, 39]. Однако полученные данные по составу ОВ в разных по типу (термальные воды, высокотемпературный раствор, пароводяная смесь) и обстановкам (обитаемая и необитаемая области) гидротермальных системах не сравнивались между собой. Также не рассматривались особенности биотического и абиотического круговорота ОВ в изученных гидротермальных системах ДВ. Учитывая слабую изученность данных процессов в дальневосточных гидротермальных системах, цель настоящего исследования - провести сравнительный анализ состава ОВ в разных по типу и обстановкам гидротермальных системах ДВ и выявить наиболее характерные органические соединения, формирующие частные биотический и абиотический круговороты.

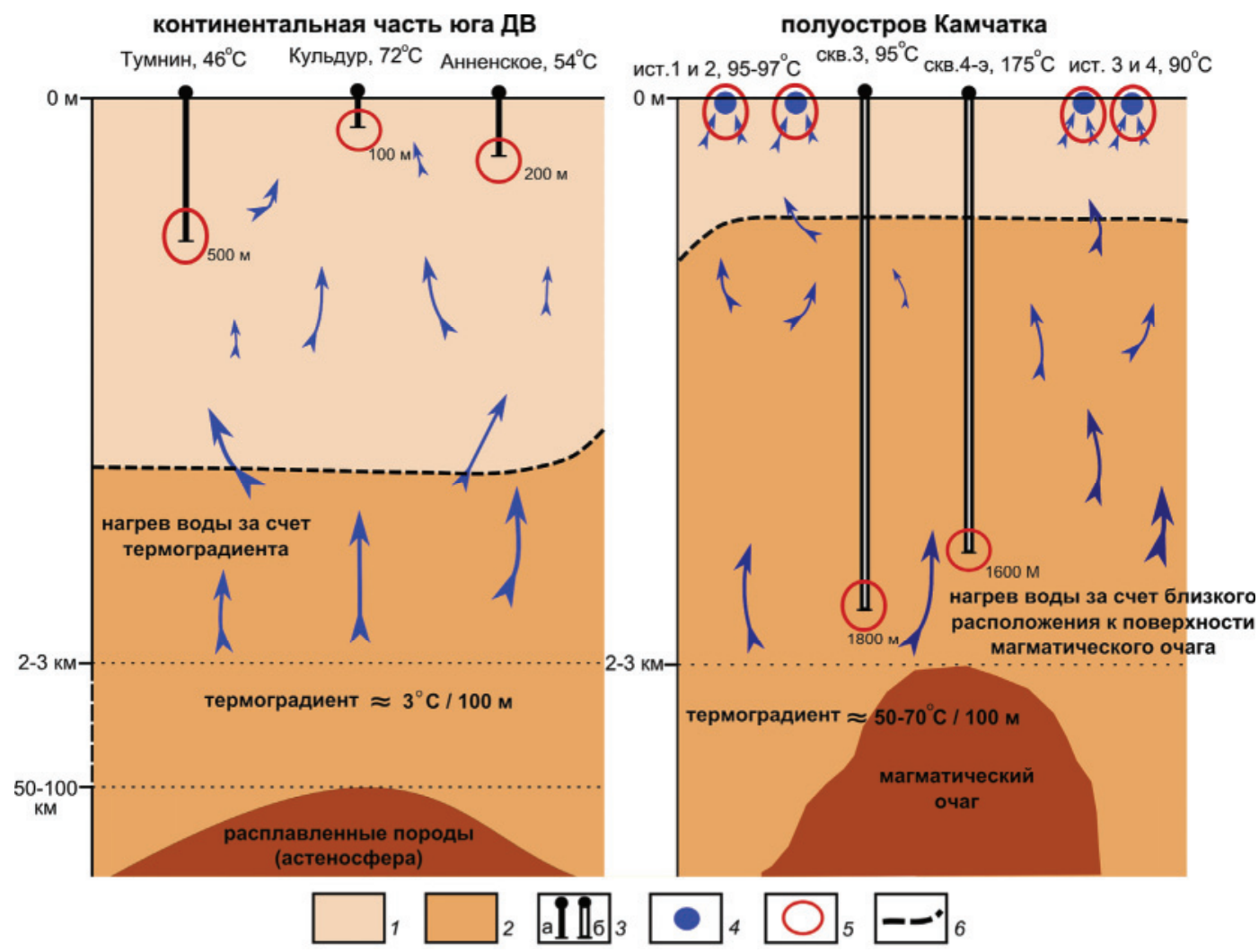

Pис. 1. Расположение мест опробования гидротермального флюида в пределах обитаемой и необитаемой зон изученных гидротермальных систем: 1 - обитаемая зона гидротермальных систем; 2 - необитаемая зона гидротермальных систем; 3 - скважины с выходом: а) термальной воды, б) перегретой пароводяной смеси; 4 - естественные выходы горячих источников; 5 - области опробования гидротермальных систем; 6 - ориентировочная граница обитаемой и необитаемой зон гидротермальных систем

Fig. 1. Location of hydrothermal fluid sampling sites within inhabited and uninhabited zones of hydrothermal systems studied: 1 is the inhabited zone of hydrothermal systems; 2 is the uninhabited zone of hydrothermal systems; 3 are the wells with the output of: a) thermal water, b) superheated steam-water mixture; 4 are the natural outlets of hot springs; 5 are the areas of testing of hydrothermal systems; 6 is the indicative boundary of inhabited and uninhabited zones of hydrothermal systems 


\section{Объекты и методы исследования}

Гидротермальные системы п-ова Камчатка

В качестве объектов исследования были выбраны Мутновский и Паратунский геотермальные районы, расположенные на юго-востоке полуострова (рис. 2). В пределах этих районов были обследованы как естественные выходы горячих источников, так и глубокие скважины, выводящие на поверхность высокотемпературные растворы и пароводяную смесь.

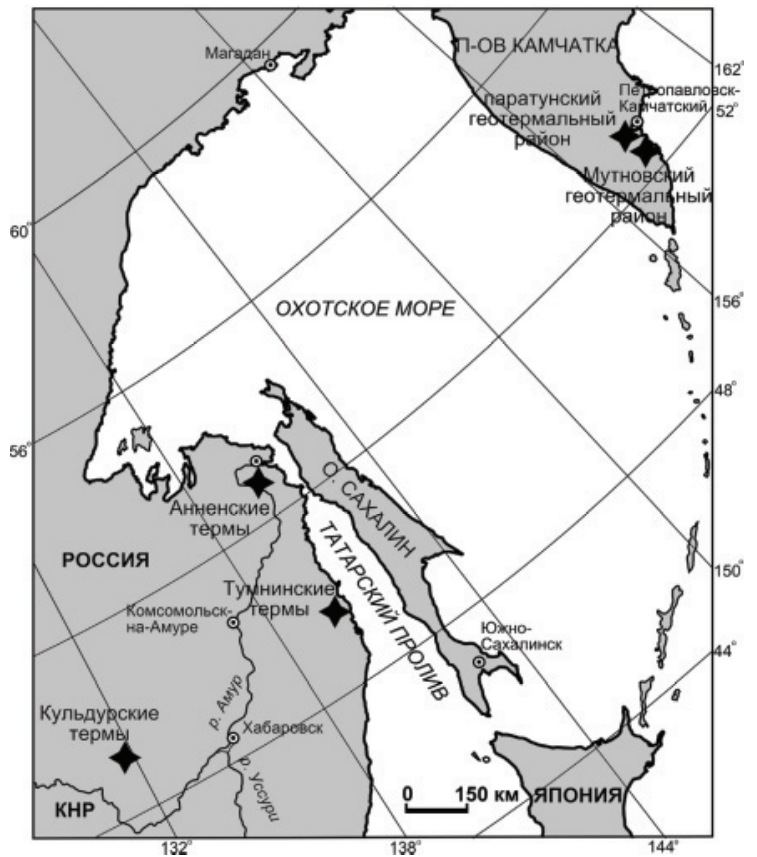

Рис. 2. Обзорная карта с местом расположения исследуемых гидротермальных систем Дальнего Востока

Fig. 2. Survey map with the location of the investigated hydrothermal systems of the Far East

Пароводяная слесь. Были опробованы три глубоких скважины (глубиной более 1000 м). Две из них - скважины Мутновского геотермального района - дают на выходе пароводяную смесь. Интерес к изучению ОВ в конденсатах пароводяной смеси заключается в том, что при очень высокой температуре они являются стерильными. Соответственно, обнаруженные в них органические соединения не могут являться прямыми продуктами деструкции микроорганизмов, что предполагает их генезис за счет абиогенного хемосинтеза, включая ре-синтез первично биогенного материала, извлеченного из вмещающих пород. Кроме этого, глубина скважин позволяет опробовать безжизненную необитаемую область (учитывая высокий термоградиент) гидротермальных систем (рис. 1). Конденсат смеси был отобран из скважины № 4-Э Дачного термального поля, глубиной 1600 м и температурой на выходе $175{ }^{\circ} \mathrm{C}$ (содержание жидкой фазы в пределах 10 \%), и скважины № 3 СевероМутновского термального поля. Эта скважина является открытой и фонтанирует на высоту до
40-50 м. Глубина 1800 м, температура на выходе $97{ }^{\circ} \mathrm{C}$. Возможность наличия микроорганизмов в смеси из скважины № 3 представляется маловероятной, учитывая высокий геотермический градиент в пределах термального района (быстрое повышение температуры с глубиной) и существенное преобладание пара над жидкой фазой.

Высокотелпературный раствор. Третья глубокая скважина № ГК-9 вскрывает Нижнепаратунские источники Паратунского геотермального района. Глубина скважины 1080 м. На выходе температура воды $-82{ }^{\circ} \mathrm{C}$, поэтому скважина дает не пароводяную смесь, а высокотемпературный раствор. На Нижнепаратунском термальном поле проводились микробиологические исследования, и в естественных горячих источниках были установлены различные термофильные цианобактерии [40]. Раствор из глубоких скважин, вскрывающих Нижнепаратунские термальные воды, не подвергался микробиологическому анализу, однако, учитывая высокую температуру воды на выходе, высокий термоградиент в пределах месторождения (50-70 ${ }^{\circ} \mathrm{C}$ на каждые 100 м) [32] и глубину скважины (1080 м), наличие здесь термофильных микроорганизмов представляется маловероятным. Кроме этого, скважина, имеющая глубину более 1000 м, вскрывает безжизненную область гидротермальной системы (температура глубинного резервуара Паратунской системы составляет около $126{ }^{\circ} \mathrm{C}$ [33]), поэтому на глубине это практически стерильная пароводяная смесь, в которой жизни быть не может. При этом следует отметить и сходство состава ОВ здесь с составом ОВ в стерильном конденсате пароводяной смеси. Однако вопрос о наличии в высокотемпературном растворе скважины ГК-9 гипертермофилов остается открытым.

Eстественные выходы горячих источников Мутновского района. Всего было опробовано 4 горячих источника - по 2 в Дачном и Донном термальных полях. Во всех источниках наблюдается заметный выход газовых пузырьков. Их температура превышает $90{ }^{\circ} \mathrm{C}$, являясь близкой к точке кипения для соответствующего гипсометрического уровня. Имеющиеся данные по микробиоте гидротерм Камчатки, в частности в термах Мутновского района и кальдеры вулкана Узон [4, 41-43], позволяют предполагать наличие в них гипертермофильных архей и бактерий. В верхней части Дачного поля опробован кипящий водяной котел $1 \mathrm{c}$ небольшой примесью глины размером $0,4 \times 0,4$ м, имеющий $\mathrm{pH} 3,5$. Другой опробованный кипящий котел 2 Дачного поля, имеющий сходный состав $(\mathrm{pH} 3)$ и размеры $0,8 \times 1 \mathrm{~m}$, расположен в его нижней части. В нижней части Донного фумарольного поля для опробования был выбран большой кипящий источник 1 с прозрачной водой, имеющий размер $1 \times 1,5$ м, располагающийся под большой фумаролой. Наиболее крупным в пределах Донного фумарольного поля является кипящий грязевой котел 2 , расположенный в его самой верхней части. Размер котла примерно $5 \times 10$ м. 
Гидротермальные системы континентальной части юга Дальнего Востока

В качестве объектов исследования в этой части Дальнего Востока выбраны три крупных геотермальных месторождения - Кульдурское, Анненское и Тумнинское (рис. 2). Их естественные выходы давно ликвидированы, месторождения разведаны скважинами. В настоящее время термальная вода вскрывается и выводится на поверхность неглубокими скважинами (глубиной от 100 до 500 м). Учитывая невысокий термоградиент, скважины попадают в обитаемую область гидротермальных систем (рис. 1). Это типичные напорные трещинно-жильные воды, нагревающиеся за счет нормального термоградиента. Наиболее горячая вода - Кульдурская - имеет температуру $72{ }^{\circ} \mathrm{C}$, позволяющую развиваться здесь термофильным комплексам. Даже на глубине порядка 2-3 км, в глубинном резервуаре гидротермальной системы температура воды по разным данным составляет от 103 до 110 ㄷ [30-32], что позволяет даже на таких глубинах гипотетически предположить наличие гипертермофилов. В воде из Кульдурских эксплуатационных скважин были обнаружены термофильные микроорганизмы рода Thermus aquaticus [36]. Установлено, что для бактерий рода Thermus характерна первая форма гена РуБисКО. Это говорит об участии этих термофилов в цикле Кальвина-Бенсона, который является наиболее распространённым из механизмов автотрофной фиксации $\mathrm{CO}_{2}$. Микроорганизмы, обладающие этим циклом, обычно не рассматриваются как продуценты OB в гидротермах из-за термолабильности некоторых его интермедиатов (если температура воды выше $75{ }^{\circ} \mathrm{C}$ ) [41]. На Анненском и Тумнинском месторождении температура воды еще ниже - 54 и $46{ }^{\circ} \mathrm{C}$ соответственно. В этих источниках не проводились микробиологические изыскания, однако, учитывая благоприятную температуру, здесь также можно предполагать наличие сообществ термофильных микроорганизмов.

\section{Методика исследования}

При проведении исследования был осуществлен сбор и изучение ранее опубликованных статей [34-39]. Для обследования месторождений термальных вод на территории Дальнего Востока и отбора проб воды выполнялись полевые маршруты. Отбор проб производился в стеклянную тару. Пробоподготовка проводилась методом твердофазной экстракции в лаборатории Хабаровского краевого центра экологического мониторинга и прогнозирования ЧС (КЦЭМП). Анализ состава ОВ средней летучести осуществлялся капиллярной газовой хроматомасс-спектрометрией на газовом хроматомасс-спектрометре Shimadzu GCMS-QP2010S в лаборатории КЦЭМП (аналитик В.Л. Рапопорт) и на Shimadzu GCMS-QP2010ultra в лаборатории ИКАРП ДВО РАН (аналитик В.А. Потурай). Были получены хроматограммы по общему ионному току (ОИТ), по которым идентифицировались орга- нические соединения средней летучести. Идентификация пиков осуществлялась по масс-спектрам и индексам удерживания (индекс Ковача). Сравнение проводилось с библиотечной (NIST, EPA) и собственной базой данных. Для более надежной идентификации спектры регистрировали в режиме селективного ионного мониторинга (СИМ) по характеристическим ионам (m/z $57 ; 60 ; 91 ; 112$; $128 ; 142 ; 178 ; 256)$. Для каждого соединения была рассчитана относительная доля в процентах. Сумма всех соединений, установленных в пробе, равнялась $100 \%$. Подробно используемая методика описана в работах [34-39].

\section{Результаты и их обсуждение}

Всего в термальных водах (в т. ч. и пароводяной смеси) обнаружено 210 органических соединений, принадлежащих 22 гомологическим рядам. В необитаемой области гидротермальных систем (стерильная пароводяная смесь и высокотемпературный раствор глубоких скважин Мутновского и Паратунского геотермальных районов) обнаружено 56 органических компонентов, которые относятся к 12 гомологическим рядам. В естественных выходах горячих источников Мутновского района выявлено 59 компонентов органической природы, принадлежащие 13 гомологическим рядам. В неглубоких скважинах термальных вод на континенте установлен наиболее разнообразный состав ОВ. Здесь найдено 151 органическое соединение средней летучести, формирующие 19 гомологических рядов.

Широкого распространения во всех типах изученных термальных вод (конденсат пароводяной смеси, высокотемпературный раствор, естественные выходы горячих источников, термальная вода из неглубоких скважин) и обстановок (обитаемая и необитаемая зоны гидротермальных систем) достигают простые УВ (предельные и ароматические). Причем их максимальные доли наблюдаются в необитаемой зоне гидротермальных систем (глубокие скважины Мутновского и Паратунского районов) и колеблются в сумме от 70 до $80 \%$. В естественных выходах изученных горячих источников п-ова Камчатки эти ряды занимают от 5 до $65 \%$, а в термальной воде из неглубоких скважин термальных полей на континенте алканы и ароматические УВ имеют от 16 до 98 \%. Как уже говорилось ранее, простые УВ (чаще всего предельные) способны синтезироваться абиогенно в высокотемпературных источниках на дне океанов [5-15]. В пароводяной смеси необитаемой области эти компоненты не могут иметь биогенный генезис, поскольку флюид обладает температурой $175{ }^{\circ} \mathrm{C}$, при которой даже бактериальная жизнь является невозможной. Также нет основания считать обнаруженные УВ продуктом абиогенного хемосинтеза (т. е. синтез УВ из неорганических соединений). Вероятно, основная часть УВ, установленных в конденсате пароводяной смеси, имеет термогенный генезис (образование УВ в результате 
термодиссоциации при высоких температурах органических остатков, извлеченных из вмещающих пород). Кроме этого, особенности молекулярномассового распределения алканов в Нижнепаратунских источниках также свидетельствуют о термогенном синтезе предельных УВ в высокотемпературном флюиде, а в континентальных термальных водах (Кульдурские и Анненские источники) УВ образовались в результате химического ре-синтеза органических остатков растительного происхождения [44].

Таблица 1. Гомологические ряды органических соединений в обитаемой и необитаемой зонах гидротермальных систем п-ва Камчатка, по [38, 39]

Table 1. Homological series of organic compounds in the inhabited and uninhabited zones of hydrothermal systems of the Kamchatka Peninsula, according to [38, 39]

\begin{tabular}{|c|c|c|c|c|c|c|c|}
\hline \multirow{3}{*}{$\begin{array}{c}\text { Гомологический } \\
\text { ряд } \\
\text { Homology series }\end{array}$} & \multicolumn{3}{|c|}{\begin{tabular}{|c|} 
Глубокие скважины \\
(необитаемая зона) \\
Deep wells \\
(uninhabited zone)
\end{tabular}} & \multicolumn{4}{|c|}{$\begin{array}{c}\text { Естественные выходь } \\
\text { горячих источников* } \\
\text { Hot Springs }\end{array}$} \\
\hline & № 4-Э & № 3 & № ГК-9 & 1 & 2 & 3 & 4 \\
\hline & \multicolumn{7}{|c|}{ Доля/Content, \% } \\
\hline Алканы/Alkanes & 17 & 33 & 19 & 32 & 3 & 33 & 19 \\
\hline \begin{tabular}{|l|} 
Изоалканы \\
Isoalkanes
\end{tabular} & 7 & - & - & 1 & 0,2 & 7 & - \\
\hline \begin{tabular}{|l|} 
Изоалкены \\
Isoalkenes
\end{tabular} & - & - & - & - & 0,5 & - & - \\
\hline \begin{tabular}{|l|} 
Изопрены \\
Isoprenes
\end{tabular} & 1 & - & - & - & - & - & - \\
\hline $\begin{array}{l}\text { Циклоалканы } \\
\text { Cycloalkanes }\end{array}$ & - & - & - & - & 0,6 & 2 & - \\
\hline \begin{tabular}{|l|} 
Ароматические УВ \\
Aromatic \\
hydrocarbons
\end{tabular} & 65 & 40 & 50 & 31 & 2 & 31 & 1 \\
\hline \begin{tabular}{|l} 
Карбоновые \\
кислоты \\
Carboxylic acids
\end{tabular} & - & 3 & - & - & 42 & 4 & - \\
\hline Эфиры/Esters & - & - & 3 & 24 & 14 & 3 & 73 \\
\hline $\begin{array}{l}\text { Альдегиды } \\
\text { Aldehydes }\end{array}$ & 0,5 & - & - & - & 1 & 4 & - \\
\hline Кетоны/Ketones & 2,5 & 6 & 9 & 6 & 0,1 & 3 & - \\
\hline Спирты/Alcohols & 6 & 18 & 13 & 6 & - & 13 & 7 \\
\hline \begin{tabular}{|l|} 
Серосодержащие \\
yв \\
Sulfur-containing \\
hydrocarbons
\end{tabular} & 2 & - & - & - & - & - & - \\
\hline Терпены/Terpenes & - & - & 6 & - & 28 & - & - \\
\hline \begin{tabular}{|l} 
Стероиды \\
Steroids
\end{tabular} & - & - & - & - & 9 & - & - \\
\hline
\end{tabular}

Примечание: *1 - кипящий водяной котел 1 Дачного поля; 2 кипящий водяной котел 2 Дачного поля; 3 - кипящий водяной котел 1 Донного фумарольного поля; 4 - кипящий грязевой котел 2 Донного фумарольного поля. Полужирным выделены ряды, встречающиеся только во флюиде глубоких скважин; курсивом выделены соединения, найденные только в естественных выходах горячих источников.

Note: * 1 is the boiling water boiler 1 of the Dachnoe field; 2 is the boiling water boiler 2 of the Dachnoe field; 3 is the boiling water boiler 1 of the Donnoe fumarolic field; 4 is the boiling mud pot 2 of the Donnoe fumarolic field. Bolded rows were found only in the fluid of deep wells; italicized compounds were found only in the natural outlets of hot springs.
Остальные ряды органических соединений, типичные для необитаемой области изученных гидротермальных систем, представлены спиртами и кетонами (табл. 1). В естественных выходах горячих источников эти компоненты также значительно распространены, а для термальных вод на континенте они не характерны. Таким образом, в термальных водах вулканических областей, в отличие от континентальных термальных вод, доминируют простые УВ, спирты и кетоны. Обращает внимание наличие только в пароводяной смеси необитаемой зоны Мутновской гидротермальной системы изопренов - пристана и фитана. Причем найдены они в конденсате смеси из скважины 4-Э, которая дает наиболее высокотемпературный флюид из изученных.

В естественных выходах горячих источников Мутновского района, кроме простых УВ (алифатических и ароматических), спиртов и кетонов, широко развиты карбоновые кислоты и их эфиры (в сумме от 7 до $73 \%$ ). Эти соединения, преимущественно биогенного происхождения, появились здесь, по-видимому, в результате контакта термальных вод с приповерхностным почвенным слоем, содержащим биогенные органические остатки. Эти компоненты широко представлены и в термальных водах из неглубоких скважин на континенте (т. е. тоже в обитаемой зоне гидротермальных систем). Их относительные содержания здесь находятся в пределах от 6 до 80 \% (табл. 2). Терпены и стероиды - явно биогенные компоненты, наблюдаются в изученных термальных водах Камчатки только в одном месте - кипящий водяной котел № 2 Дачного термального поля. Здесь относительные содержания этих соединений достигают в сумме $37 \%$ и также, по-видимому, являются следствием контакта горячей воды с почвами и деятельностью сообществ термофильных микроорганизмов. К специфичным соединениям, которые встречаются только в естественных выходах горячих источников Мутновского района, относятся изомеры предельных и непредельных УВ - изоалкены и циклоалканы или нафтены. Наличие различных изомеров преимущественно предельных УВ является характерной чертой термальных вод.

Наиболее разнообразный состав ОВ наблюдается в термальных водах изученных гидротермальных систем в континентальной части юга Дальнего Востока, вскрываемых неглубокими скважинами. Здесь установлен 151 компонент, относящийся к 21 гомологическому ряду. Наряду с простыми УВ (алифатическими и ароматическими), карбоновыми кислотами и их әфирами, широко распространены альдегиды и терпены. Эти компоненты, так же как и карбоновые кислоты и их эфиры, - биогенного генезиса, что не удивительно, учитывая сравнительно невысокую температуру, которая позволяет существовать различным термофильным комплексам. $K$ тому же скважины вскрывают именно обитаемую зону гидротермальных систем. Поэтому, в результате деятельности и деструкции 
термофильных микроорганизмов, населяющих эту зону, и поступают в термальные воды указанные выше соединения. Кроме этого, в термальных водах из неглубоких скважин установлен целый комплекс гомологических рядов органических соединений, которые отсутствуют в других типах изученных термальных вод и флюиде - это непредельные УВ (алкены), изомеры предельных УВ (диэтоксиалканы и диоксаалканы), азотсодержащие соединения, галогенароматические УВ (хлорбензол) и хиноны. В частности, этим тоже отличается состав ОВ континентальных термальных вод от состава ОВ гидротермальных систем зоны перехода от континента к океану. Стоит отметить, что хлорбензол установлен только в термальной воде из скважины № 2 Анненского месторождения и его наличие связано либо с взаимодействием в системе «вода - осадочная порода», либо с его извлечением из материала пластиковых труб, по которым поступает вода от насоса к накопительному резервуару [35].

Таблица 2. Гомологические ряды органических соединений в термальной воде из неглубоких скважин, изученных континентальных гидротермальных систем по $[34,35,37]$

Table 2. Homological series of organic compounds in thermal water from shallow boreholes, studied continental hydrothermal systems, according to [34, 35, 37]

\begin{tabular}{|c|c|c|c|c|c|c|c|c|}
\hline \multirow{3}{*}{$\begin{array}{c}\text { Гомологический ряд } \\
\text { Homology series }\end{array}$} & \multicolumn{4}{|c|}{$\begin{array}{l}\text { Кульдур* } \\
\text { Kuldur }\end{array}$} & \multicolumn{2}{|c|}{$\begin{array}{l}\text { Анненское* } \\
\text { Annenskoye }\end{array}$} & \multicolumn{2}{|c|}{$\begin{array}{l}\text { Tyмнин* } \\
\text { Tumnin }\end{array}$} \\
\hline & K1 & $\mathrm{K} 2$ & K3 & K4 & A1 & $\mathrm{A} 2$ & $\mathrm{~T} 1$ & $T 2$ \\
\hline & \multicolumn{8}{|c|}{ Доля/Content, \% } \\
\hline Алканы/Alkanes & 18 & 39 & 15 & 19 & 50 & 16 & 17 & 27 \\
\hline Изоалканы/Isoalkanes & - & - & - & 2 & 2 & 1,5 & 1,5 & 9,5 \\
\hline Алкены/Alkenes & - & - & - & - & - & 1 & 0,5 & - \\
\hline $\begin{array}{l}\text { Диэтоксиалканы } \\
\text { Diethoxyalkanes }\end{array}$ & 2 & - & - & - & - & - & - & - \\
\hline $\begin{array}{l}\text { Диоксаалканы } \\
\text { Dioxaalkanes }\end{array}$ & - & - & - & - & 2 & 3 & - & - \\
\hline $\begin{array}{l}\text { Ароматические } \\
\text { углеводороды } \\
\text { Aromatic hydrocarbons }\end{array}$ & 80 & 45 & 1,5 & 2 & - & - & 20 & 5 \\
\hline $\begin{array}{l}\text { Карбоновые кислоты } \\
\text { Carboxylic acids }\end{array}$ & - & - & 67 & 20 & 6 & 5 & 0,5 & - \\
\hline Эфиры/Esters & - & - & 13 & 15 & 26 & 59 & 7 & 6 \\
\hline Альдегиды/Aldehydes & - & 16 & - & 3 & 2 & 2 & 2,5 & 2 \\
\hline Кетоны/Ketones & - & - & - & 2 & 1 & 1 & 0,4 & - \\
\hline Спирты/Alcohols & - & - & - & 3 & 5 & 8 & 0,4 & - \\
\hline $\begin{array}{l}\text { Азотсодержащие } \\
\text { соединения } \\
\text { Nitrogen-containing } \\
\text { compounds }\end{array}$ & - & - & - & - & 0,2 & 1,5 & - & - \\
\hline $\begin{array}{l}\text { Галогенаромати- } \\
\text { ческие УВ } \\
\text { Halogenoaromatic } \\
\text { hydrocarbons } \\
\end{array}$ & - & - & - & - & 1,5 & - & - & - \\
\hline $\begin{array}{l}\text { Серосодержащие УВ } \\
\text { Sulfur-containing } \\
\text { hydrocarbons }\end{array}$ & - & - & - & - & - & - & 1 & - \\
\hline Терпены/Terpenes & - & - & 3,5 & 18 & 4 & 0,5 & 47 & 49 \\
\hline Стероиды/Steroids & - & - & - & 8 & 1 & 2,5 & 0,4 & - \\
\hline Хиноны/Quinones & - & - & - & - & & & 1 & 3 \\
\hline
\end{tabular}

Кроме этого, проводились и исследования ОВ в холодных подземных и поверхностных водах [35-37] районов континентальных термальных вод Дальнего Востока. Согласно полученным результатам, в холодных водных экосистемах преобладают явно биогенные компоненты - терпены, стероиды, карбоновые кислоты и эфиры. Также значительное содержание демонстрируют алканы, но их происхождение (принимая во внимания значение индексов нечетности и особенности молекулярно-массового распределения УВ) связано здесь с бактериальной деятельностью. Эти компоненты типичны для холодных вод и донных осадков [45-50]. В отличие от них, в термальных водах преобладают алканы и ароматические УВ, причем алканы образованы в результате химического ресинтеза органических остатков. Различные изомеры предельных УВ, которые являются типичными для термальных вод, в холодных водах вообще не установлены.

\section{Заключение}

В результате проведенного исследования в гидротермальных системах Дальнего Востока разных типов (пароводяная смесь, высокотемпературный раствор, термальная вода) и обстановок (обитаемая и необитаемая области) установлено 210 органических соединений, принадлежащих 22 гомологическим рядам. Характерной чертой всех изученных горячих вод и флюида является преобладание простых УВ (предельных и ароматических). Предельные УВ образованы здесь, вероятно, в результате термогенных процессов под действием высоких температур (Мутновский и Паратунский геотермальные районы) и химического ре-синтеза органических остатков растительного происхождения (Кульдурские и Анненские термальные воды). Следует отметить, что в основном только эти компоненты формируют абиогенный круговорот OВ во флюиде из необитаемой зоны. Изомеры УВ также являются типичными компонентами в изученных горячих водах Дальнего Востока. В воде горячих источников Камчатки и из неглубоких скважин континентальных термальных полей, кроме простых УВ, широко распространены биогенные карбоновые кислоты и их эфиры, а в континентальных термальных водах еще и биогенные альдегиды и терпены. Эти соединения в основном формируют биогенный круговорот ОВ в гидротермальных системах.

Примечание: * К1-К4 - Кульдур, скважина 1-87 (годы, когда отбиралась проба: 2007, 2008, 2011 и 2013 гг.); А1 - Анненское, скважина 2; А2 - Анненское, скважина 21; Т1 - Тумнин, скважина 8; T2 - Тумнин, скважина 9. Полужирным выделены ряды, установленные только в неглубоких скважинах континентальных термальных полей.

Note: * K1-K4 - Kuldur, well 1-87 (years, when the sample was selected: 2007, 2008, 2011 and 2013); A1 - Annenskoe, well 2; A2 - Annenskoe, well 21; T1 - Tumnin, borehole 8; T2 - Tumnin, borehole 9. Bolded rows are established only in shallow wells of continental thermal fields. 
Отличительной особенностью термальных вод и флюида п-ова Камчатка от континентальных терм является более широкое распространение предельных и ароматических УВ, спиртов, кетонов, а также наличие изопренов, изоалкенов и циклоалканов. Наиболее разнообразный состав ОВ наблюдается в термальных водах на континенте. Здесь, наряду с УВ и биогенными карбоновыми кислотами и их

\section{СПИСОК ЛИТЕРАТУРЫ}

1. Калитина Е.Г., Харитонова Н.А., Вах Е.А. Распространение бактерий различных эколого-трофических групп в подземных термальных водах Кульдурского месторождения (Дальний Восток России) // Современные проблемы науки и образования. -2017 . - № 5. - С. 351

2. Филогенетическое и функциональное разнообразие прокариот мезотермального минерального источника Хойто-Гол (Восточный Сан, Бурятия) / Е.С. Кашкак, Н.Л. Белькова, Э.В. Данилова, О.П. Дагурова, Б.Б. Намсараев, В.М. Горленко // Микробиология. - 2016. - Т. 85. - № 5. - С. 555-567.

3. Способность гипертермофильных Crenarchaeta к разложению труднодоступных белков ( $\alpha$ - и $\beta$-кератинов) / С.Х. Биджиева, К.С. Дербикова, И.В. Кубланов, Е.А. Бонч-Осмоловская // Микробиология. - 2014. - Т. 83. - № 6. - С. 743-751.

4. Варфоломеев С.Д. Жизнь молекул в экстремальных условиях: горячий микромир Камчатки. - М.: КРАСАНД, 2013. - 480 c.

5. Aubrey A., Cleaves H., Bada J. The role of submarine hydrothermal systems in the synthesis of amino acids // Origin of Life and Evolution of Biospheres. - 2009. - V. 39. - P. 91-108. DOI: 10.1007/s11084-008-9153-2.

6. Corliss J.B., Baross J.A., Hoffman S.E. An hypothesis concerning the relationship between submarine hot springs and the origin of life on the Earth // Oceanologica Acta. - 1981. - № 4. P. 59-69.

7. Natural evidence for rapid abiogenic hydrothermal generation of $\mathrm{CH}_{4}$ / J. Fiebig, A.B. Woodland, J. Spangenberg, W. Oschmann // Geochimica et Cosmochimica Acta. - 2007. - V. 71. - P. 3028-3039. DOI: $10.1016 /$ j.gca.2007.04.010.

8. Abiotic formation of hydrocarbons under hydrothermal conditions: constraints from chemical and isotope data / Q. Fu, L.B. Sherwood, J. Horita, G. Lacrampe-Couloume, W.E. Seyfried // Geochimica et Cosmochimica Acta. - 2007. - V. 71. - P. 1982-1998 DOI: $10.1016 /$ j.gca.2007.01.022.

9. Fu Q., Socki R.A., Niles P.B. Evaluating reaction pathways of hydrothermal abiotic organic synthesis at elevated temperatures and pressures using carbon isotopes // Geochimica et Cosmochimica Acta. 2015. - V. 154. - P. 1-17. DOI: doi.org/10.1016/j.gca.2015.01.027.

10. Hennet R.J.C., Holm N.G., Engel M.H. Abiotic synthesis of amino acids under hydrothermal conditions and the origin of life: a perpetual phenomenon // Naturwissenschaften. - 1992. V. 79. - P. 361-365.

11. Holm N.G. Marine hydrothermal systems and the origin of life // Origins of Life and Evolution of Biospheres. - 1992. - V. 22. P. 1-242.

12. Holm N.G., Charlou J.L. Initial indications of abiotic formation of hydrocarbons in the Rainbow ultramafic hydrothermal system, Mid-Atlantic Ridge // Earth and Planet Sci. Lett. - 2001. V. 191. - P. 1-8

13. Holm N.G., Hennet R.I.C. Hydrothermal systems: Their varieties, dynamics, and suitability for prebiotic chemistry // Origins of Life and Evolution of Biospheres. - 1992. - V. 22. - P. 1-31.

14. Horita J., Berndt M.E. Abiogenic methane formation and isotopic fractionation under hydrothermal conditions // Science. 1999. - V. 285. - P. 1055-1057. эфирами, альдегидами и терпенами, присутствуют алкены, диэтоксиалканы, диоксаалканы, азотсодержащие соединения и хиноны, наличие которых не установлено в термальных водах Камчатки.

Автор благодарит научного руководителя к.г.-м.н. В.Н. Компаниченко, под руководством которого проводились полевые исследования гидротермальных систем Камчатки, за помощь в обсуждении полученных результатов.

15. The production of methane, hydrogen, and organic compounds in ultramafic-hosted hydrothermal vents of the Mid-Atlantic Ridge / C. Konn, J.L. Charlou, N.G. Holm, O. Mousis // Astrobiology. 2015 - V. 15 - № 5. - P. 381-399. DOI: 10.1089/ast.2014.1198.

16. Синтез углеводородов при конверсии $\mathrm{CO}_{2}$ флюида водородом: экспериментальное моделирование при 7,8 ГПа и $1350{ }^{\circ} \mathrm{C} /$ А.Г. Сокол, А.А. Томиленко, Т.А. Бульбак, Н.В. Соболев // ДАН. - 2017. - Т. 477. - № 6. - С. 699-703.

17. Cleaves H.J., Aubrey A.D., Bada J.L. An evaluation of critical parameters for abiotic peptide synthesis in submarine hydrothermal systems // Origins of Life and Evolution of Biospheres. 2009. - V. 39. - P. 109-126. DOI: 10.1007/s11084-008-9154-1.

18. New insight into the contributions of thermogenic processes and biogenic sources to the generation of organic compounds in hydrothermal fluids / C. Konn, D. Testemale, J. Querellou, N.G. Holm, J.L. Charlou // Geobiology. - 2011. - V. 9. - № 1. P. 79-93. DOI: $10.1111 / j .1472-4669.2010 .00260$.x.

19. McCollom T.M. Laboratory simulations of abiotic hydrocarbon formation in Earth's deep subsurface // Reviews in Mineralogy and Geochemistry. - 2013. - V. 75. - P. 467-494. DOI: 10.2138/rmg.2013.75.15.

20. MCCollom T.M., Seewald J.S. Abiotic synthesis of organic compounds in deep-sea hydrothermal environments / / Chemical Reviews. 2007. - V. 107. - № 2. - P. 382-401. DOI: 10.1021/cr0503660.

21. Shock E., Canovas P. The potential for abiotic organic synthesis and biosynthesis at seafloor hydrothermal systems // Geofluids. 2010. -V.10. - P.161-192. DOI: 10.1111/j.1468-8123.2010.00277.x.

22. Бескровный Н.С., Лебедев Б.А. Нефтепроявление в кальдере вулкана Узон // Доклады АН СССР. - 1971. - Т. 201. - № 4. C. $953-956$.

23. Углеводороды из вулканического района. Нефтепроявления в кальдере вулкана Узон на Камчатке / Э.М. Галимов, В.С. Севастьянов, Г.А. Карпов, А.И. Камалеева, О.В. Кузнецова, И.В. Коноплева, Л.Н. Власова // Геохимия. - 2015. - № 12. C. $1059-1068$.

24. Кальдера вулкана Узон (Камчатка) - уникальная природная лаборатория современного нафтидогенеза / А.Э. Конторович, С.Б. Бортникова, Г.А. Карпов, В.А. Каширцев, Е.А. Костырева, А.Н. Фомин // Геология и геофизика. - 2011. - Т. 52. № 8. - C. 986-990.

25. Simoneit B.R.T., Deamer D.W., Kompanichenko V.N. Characterization of hydrothermally generated oil from the Uzon caldera, Kamchatka // Applied Geochemistry. - 2009. - V. 24. - P. 303-309. DOI: $10.1016 /$ j.apgeochem.2008.10.007.

26. Исидоров В.А., Зенкевич И.Г., Карпов Г.А. Летучие органические соединения в парогазовых выходах некоторых вулканов и гидротермальных систем Камчатки // Вулканология и сейсмология. - 1991. - № 3. - С. 19-25.

27. Аминокислоты в гидротермах Южной Камчатки / Л.М. Мухин, В.Б. Бондарев, Е.А. Вакин, Н.И. Ильюхина, В.И. Калиниченко, Е.И. Милехина, Э.Н. Сафонова // Доклады АН CCCP. - 1979. - T. 244. - № 4. - С. 974-977.

28. Архипов Б.С. Химический состав и металлоносность термальных вод северо-восточного Сихотэ-Алиня // Тихоокеанская геология. - 2009. - Т. 28. - № 4. - С. 116-122. 
29. Гидрогеохимия термальных источников вулкана Мутновский (Южная Камчатка) / С.Б. Бортникова, Г.М. Гавриленко, Е.П. Бессонова, А.С. Лапухов // Вулканология и сейсмология. -2009 . - № 6. - С. 26-43.

30. Кулаков В.В. Геолого-структурные и геотермальные условия формирования термальных подземных вод Приамурья // Тихоокеанская геология. - 2014. - Т. 33. - № 5. - С. 66-79.

31. Кулаков В.В., Сидоренко С.В. Минеральные воды и лечебные грязи Приамурья. - Хабаровск: Изд-во ДВГМУ, 2017. - 474 с.

32. Чудаев 0.В. Состав и условия образования современных гидротермальных систем Дальнего Востока России. - Владивосток: Дальнаука, 2003. - 216 с.

33. Геохимические особенности распределения основных и редкоземельных элементов в Паратунской и Большебанной гидротермальных системах Камчатки / О.В. Чудаев, Г.А. Челноков, И.В. Брагин, Н.А. Харитонова, С.Н. Рычагов, А.А. Нуждаев, И.А. Нуждаев // Тихоокеанская геология. - 2016. - Т. 35. № 6. - C. 102-119.

34. Компаниченко В.Н., Потурай В.А. Вариации состава органического вещества в водах Кульдурского геотермального месторождения // Тихоокеанская геология. - 2015. - Т. 34. - № 4. C. $96-107$.

35. Потурай В.А. Органическое вещество в подземных и поверхностных водах района Анненского геотермального месторождения (Дальний Восток) // Геохимия. - 2017. - № 4. - С. 372-380.

36. Потурай В.А. Органическое вещество в подземных и поверхностных водах района Кульдурского месторождения термальных вод, Дальний Восток России // Вестник КРАУНЦ. Науки о Земле. - 2013. - № 1. - Вып. 21. - С. 169-182.

37. Потурай В.А. Органическое вещество в термальных и поверхностных водах района Тумнинского месторождения термальных вод, Дальний Восток России // Известия Томского политехнического университета. - 2014. - Т. 324. - № 3. - С. 44-52.

38. Компаниченко В.Н., Потурай В.А., Карпов Г.А. Органические соединения в термальных водах Мутновского района и кальдеры Узон // Вулканология и сейсмология. - 2016. - № 5. - С. 35-50.

39. Kompanichenko V.N., Poturay V.A., Shlufman K.V. Hydrothermal systems of Kamchatka as the model for prebiotic environment // Origins of Life and Evolution of Biospheres. - 2015. V. 45. - № 1-2. - P. 93-103. DOI: 10.1007/s11084-015-9429-2.

40. Ефимова М.В., Кузякина Т.И. Альгобактериальные сообщества плавающих матов Паратунской гидротермальной системы Камчатки // Успехи современного естествознания. 2004. - № 12. - C. 87-88.
41. Продукция органического вещества и разнообразие генов рибулозо-бисфосффат карбоксилазы в осадках источника Солнечный, кальдера Узон, Камчатка / Н.А. Черных, И.В. Кубланов, М.И. Прокофьева, Н.В. Пименов, Е.Н. Фролов, А.В. Марданов, А.А. Хващевская, Н.В. Гусева, А.В. Лебединский, Е.А. Бонч-Осмоловская // Микробиология. - 2017. - Т. 86. № 5. - С. 651-654.

42. Молекулярный анализ биоразнообразия микроорганизмов в источнике Заварзина, кальдера Узон, Камчатка / В.М. Гумеров, А.В. Марданов, А.В. Белецкий, Е.А. Бонч-Осмоловская, Н.В. Равин // Микробиология. - 2011. - Т. 80. - № 2. C. $258-265$.

43. Разнообразие метаногенных архей в наземном горячем источнике 2012 (Долина гейзеров, Камчатка) / А.Ю. Меркель, 0.А. Подосокорская, Т.Г. Соколова, Е.А. Бонч-Осмоловская // Микробиология. - 2016. - Т. 85. - № 3. - С. 327-336.

44. Потурай В.А. Состав и распределение н-алканов в азотных термах Дальнего Востока России // Тихоокеанская геология. 2017. - Т. 36. - № 4. - С. 109-119.

45. Озеро Эбейты, Россия: химико-органический и минеральный состав воды и донных отложений / М.Н. Колпакова, О.Л. Гаськова, О.С. Наймушина, С.К. Кривоногов // Известия Томского политехнического университета. Инжиниринг георесурсов. 2018. - T. 329. - № 1. - C. 111-123.

46. Органические микропримеси в пресных природных водах бассейнов Томи и Верхней Оби / А.Э. Конторович, С.Л. Шварцев, В.А. Зуев, Н.М. Рассказов, Ю.П. Туров // Геохимия. - 2000. № 5. - С. 533-544.

47. Углеводороды и кислородорганические соединения в донных отложениях озер Алтая и Хакасии / О.В. Серебренникова, И.В. Русских, Е.А. Гулая, Е.Б. Стрельникова, П.Б. Кадычагов // Известия Томского политехнического университета. - 2013. T. 322. - № 1. - C. 130-135.

48. Серебренникова 0.В., Стрельникова Е.Б., Русских И.В. Особенности состава органических соединений донных отложений озер таежных и степных районов Сибири // Геохимия. 2017. - № 12. - C. 1100-1114.

49. Degens Egon T. Geochemistry of sediments: a brief survey. - New Jersey: Prentice-Hall, 1965. - $342 \mathrm{p}$.

50. Hunt J.M. Petroleum geochemistry and geology. - San Francisco: W.H. Freeman and Company, 1979. -617 p.

Поступила 21.02.2018 г.

\section{Информация об авторах}

Потурай B.A., научный сотрудник лаборатории экологии, генетики и эволюции Института комплексного анализа региональных проблем ДВО РАН. 
UDC 550.461(571.6)

\title{
ORGANIC MATTER IN HYDROTHERMAL SYSTEMS OF THE FAR EAST OF DIFFERENT TYPES AND SITUATIONS
}

\author{
Valery A. Poturay, \\ poturay85@yandex.ru \\ Institute for Complex Analysis of Regional Problems Far Eastern Branch Russian Academy of Sciences, \\ 4, Sholem-Aleichem street, Birobidzhan, 679000, Russia.
}

The relevance of the research is determined by the need to study the composition of organic matter in the inhabited and uninhabited areas of hydrothermal systems of different types. Organic compounds in thermal waters inhabited by communities of thermophiles and devoid of life (sterile steam-water mixture) form the biotic and abiotic circulation of organic matter, respectively. Taking into account poor knowledge of these processes in the Far Eastern hydrothermal systems, the study of the composition and genesis of the organic matter in them is important for detecting the patterns of matter transformation during the course of the cycle. In addition, the data on organic matter in the inhabited and uninhabited areas of hydrothermal systems are important for regional ecology and balneology, since thermal waters are used to treat people in sanatoriums and balneal hospitals.

The main aim of the research is to carry out a comparative analysis of the composition of organic matter in different types and conditions of hydrothermal systems of the Far East and to identify the most characteristic organic compounds forming private biotic and abiotic cycles.

Objects: hydrothermal systems of the continental part of the south of the Far East (thermal water from shallow wells of the Kuldur, Annensky and Tumnin of geothermal deposits) and the peninsula of Kamchatka (sterile steam-water mixture, high-temperature solution and hot springs of the Mutnovsky and Paratunsky geothermal regions).

Methods: field routes, solid-phase extraction, capillary gas chromatography-mass spectrometry, calculation of oddness indices, cartographic method.

Results. There are 210 organic compounds belonging to 22 homologous series. A characteristic feature of all the studied hot waters and fluid is the predominance of simple hydrocarbons (limiting and aromatic). Basically, only these components form an abiogenic circulation of organic matter in the fluid from the uninhabited zone. In the water of hot springs of Kamchatka and from shallow wells of continental thermal fields, in addition to simple hydrocarbons, biogenic carboxylic acids and their ethers are widely distributed, and in the thermal waters, biogenic aldehydes and terpenes are also widespread. These compounds, basically, form a biogenic circulation of organic matter in hydrothermal systems. A distinctive feature of the thermal waters and fluid of the Kamchatka Peninsula from continental terms is the wider distribution of limiting and aromatic hydrocarbons, alcohols, ketones, as well as the presence of isoprenes, isoalkenes and cycloalkanes. The most diverse composition of organic matter is observed in the thermal waters on the continent. Here, along with the components found in the thermal waters of Kamchatka, there are alkenes, diethoxyalkanes, dioxaalkanes, nitrogen-containing and chloroaromatic hydrocarbons and quinones.

\section{Key words:}

Thermal water, high-temperature solution, steam-water mixture, organic matter, biotic and abiotic cycles.

The author thanks the scientific adviser Ph.D. (earth science) V.N. Kompanichenko, under whose guidance the field studies of the hydrothermal systems of Kamchatka were conducted, for help in discussing the results obtained.

\section{REFERENCES}

1. Kalitina E.G., Kharitonova N.A., Vakh E.A. Distribution of various ecologo-trophic groups of bacteria in the underground thermal waters of the Kuldur field (Far East Russia). Sovremennye problemy nauki i obrazovanya, 2017, no. 5, pp. 351. In Rus.

2. Kashkak E.S., Bel'kova N.L., Danilova E.V., Dagurova O.P., Namsaraev B.B., Gorlenko V.M. Phylogenetic and functional prokaryotic diversity in the Hoito-Gol mesothermal mineral spring (Eastern Sayan mountains, Buryat republic). Microbiology, 2016, vol. 85, no. 5, pp. 592-603. In Rus.

3. Bidzhieva S.K., Derbikova K.S., Kublanov I.V., Bonch-Osmolovskaya E.A. Capacity of hyperthermophilic Crenarchaeota for decomposition of refractory proteins ( $\alpha$ - and $\beta$-keratins). Microbiology, 2014, vol. 83, no. 6, pp. 880-887. In Rus.

4. Varfolomeev S.D. Zhizn molekul v ekstremalnykh usloviyakh: goryachiy mikromir Kamchatki [Life of molecules under extreme conditions: the hot microcosm of Kamchatka]. Moscow, KRASAND Publ., 2013. 480 p.

5. Aubrey A., Cleaves H., Bada J. The role of submarine hydrothermal systems in the synthesis of amino acids. Origin of Life and Evolution of Biospheres, 2009, vol. 39, pp. 91-108.
6. Corliss J.B., Baross J.A., Hoffman S.E. An hypothesis concerning the relationship between submarine hot springs and the origin of life on the Earth. Oceanologica Acta, 1981, no. 4, pp. $59-69$.

7. Fiebig J., Woodland A.B., Spangenberg J., Oschmann W. Natural evidence for rapid abiogenic hydrothermal generation of $\mathrm{CH}_{4}$. Geochimica et Cosmochimica Acta, 2007, vol. 71, pp. 3028-3039. DOI: 10.1016/j.gca.2007.04.010.

8. Fu Q., Sherwood L.B., Horita J., Lacrampe-Couloume G., Seyfried W.E. Abiotic formation of hydrocarbons under hydrothermal conditions: constraints from chemical and isotope data. Geochimica et Cosmochimica Acta, 2007, vol. 71, pp. 1982-1998. DOI: 10.1016/j.gca.2007.01.022.

9. Fu Q., Socki R.A., Niles P.B. Evaluating reaction pathways of hydrothermal abiotic organic synthesis at elevated temperatures and pressures using carbon isotopes. Geochimica et Cosmochimica Acta, 2015, vol. 154, pp. 1-17. D0I: doi.org/10.1016/j.gca.2015.01.027.

10. Hennet R.J.C., Holm N.G., Engel M.H. Abiotic synthesis of amino acids under hydrothermal conditions and the origin of life: a perpetual phenomenon. Naturwissenschaften, 1992, vol. 79, pp. 361-365. 
11. Holm N.G. Marine hydrothermal systems and the origin of life. Origins of Life and Evolution of Biospheres, 1992, vol. 22, pp. 1-242.

12. Holm N.G., Charlou J.L. Initial indications of abiotic formation of hydrocarbons in the Rainbow ultramafic hydrothermal system, MidAtlantic Ridge. Earth and Planet Sci. Lett, 2001, vol. 191, pp. 1-8.

13. Holm N.G., Hennet R.I.C. Hydrothermal systems: Their varieties, dynamics, and suitability for prebiotic chemistry. Origins of Life and Evolution of Biospheres, 1992, vol. 22, pp. 1-31.

14. Horita J., Berndt M.E. Abiogenic methane formation and isotopic fractionation under hydrothermal conditions. Science, 1999, vol. 285, pp. 1055-1057.

15. Konn C., Charlou J.L., Holm N.G., Mousis 0. The production of methane, hydrogen, and organic compounds in ultramafic-hosted hydrothermal vents of the Mid-Atlantic Ridge. Astrobiology, 2015, vol. 15, no. 5, pp. 381-399. DOI: 10.1089/ast.2014.1198.

16. Sokol A.G., Tomilenko A.A., Bul'bak T.A., Sobolev N.V. Synthesis of hydrocarbons by $\mathrm{CO}_{2}$ fluid conversion with hydrogen: Experimental modeling at $7.8 \mathrm{GPa}$ and $1350^{\circ} \mathrm{C}$. Doklady Earth Sciences, 2017, vol. 477, no. 2, pp. 1483-1487. In Rus.

17. Cleaves H.J., Aubrey A.D., Bada J.L. An evaluation of critical parameters for abiotic peptide synthesis in submarine hydrothermal systems. Origins of Life and Evolution of Biospheres, 2009, vol. 39, pp. 109-126. D0I: 10.1007/s11084-008-9154-1.

18. Konn C., Testemale D., Querellou J., Holm N.G., Charlou J.L. New insight into the contributions of thermogenic processes and biogenic sources to the generation of organic compounds in hydrothermal fluids. Geobiology, 2011, vol. 9, no. 1, pp. 79-93. DOI: $10.1111 /$ j.1472-4669.2010.00260.x.

19. McCollom T.M. Laboratory simulations of abiotic hydrocarbon formation in Earth's deep subsurface. Reviews in Mineralogy and Geochemistry, 2013, vol. 75, pp. 467-494. DOI: 10.2138/rmg.2013.75.15.

20. MCCollom T.M., Seewald J.S. Abiotic synthesis of organic compounds in deep-sea hydrothermal environments. Chemical Reviews, 2007, vol. 107, no. 2, pp. 382-401. DOI: 10.1021 /cr0503660.

21. Shock E., Canovas P. The potential for abiotic organic synthesis and biosynthesis at seafloor hydrothermal systems. Geofluids, 2010, vol. 10, pp. 161-192. DOI: 10.1111/j.1468-8123.2010.00277.x.

22. Beskrovny N.S., Lebedev B.A. Nefteproyavlenie v kaldere vulkana Uzon [Oil manifestation in the caldera of the Uzon volcano]. Doklady akademii nauk SSSR, 1971, vol. 201, no. 4, pp. 953-956.

23. Galimov E.M., Sevast'yanov V.S., Kamaleeva A.I., Kuznetsova 0.V., Konopleva I.V., Vlasova L.N., Karpov G.A. Hydrocarbons from a volcanic area. Oil seeps in the Uzon caldera, Kamchatka. Geochemistry International, 2015, no. 12, pp. 1019-1027. In Rus.

24. Kontorovich A.E., Bortnikova S.B., Kashirtsev V.A., Kostyreva E.A., Fomin A.N., Karpov G.A. Uzon volcano caldera (Kamchatka): a unique natural laboratory of the present-day naphthide genesis. Russian Geology and Geophysics, 2011, vol. 52, no. 8, pp. 768-772. In Rus.

25. Simoneit B.R.T., Deamer D.W., Kompanichenko V.N. Characterization of hydrothermally generated oil from the Uzon caldera, Kamchatka. Applied Geochemistry, 2009, vol. 24, pp. 303-309. DOI: 10.1016/j.apgeochem.2008.10.007.

26. Isidorov V.A., Zenkevich I.G., Karpov G.A. Volatile organic compounds in steam-gas outflows of several volcanoes and hydrothermal systems in Kamchatka. Journal of Volcanology and Seismology, 1992, vol. 13, no. 3, pp. 287-293.

27. Muhin L.M., Bonlarev V.B., Vakin E.A., Ilyuhina N.I., Kalinichenko V.I., Milekhina E.I., Safonova E.N. Aminokisloty v gidrotermakh Yuzhnoy Kamchatki [Amino acids in the hydrothermal waters of South Kamchatka]. Doklady akademii nauk SSSR, 1979, vol. 244 , no. 4, pp. 974-977.

28. Arkhipov B.S. Chemical composition and metal content of ther mal waters of the north-eastern Sikhote-Alin (Far East). Tikhookeanskaya geologiya, 2009, vol. 28, no. 4, pp. 116-122. In. Rus.
29. Bortnikova S.B., Gavrilenko G.M., Bessonova E.P., Lapukhov A.S. The hydrogeochemistry of thermal springs on Mutnovskii volcano, Southern Kamchatka. Journal of Volcanology and Seismology, 2010, vol. 3, no. 6, pp. 388-404. In Rus.

30. Kulakov V.V. Geological-structural and hydrothermal conditions for the formation of groundwater in Priamurye. Tihookeanskaya geologiya, 2014, vol. 33, no. 5, pp. 66-79. In. Rus.

31. Kulakov V.V., Sidorenko S.V. Mineralnye vody i lechebnye gryazi Priamurya [Mineral waters and therapeutic mud of Priamurya]. Khabarovsk, DVGMU Publ., 2017. 474 p.

32. Chudaev 0.V. Sostav i usloviya obrazovaniya sovremennykh gidrotermalnykh sistem Dalnego Vostoka Rossii [Composition and conditions of formation of modern hydrothermal systems of the Far East of Russia]. Vladivostok, Dalnauka Publ., 2003. 216 p.

33. Chudaev 0.V., Chelnokov G.A., Bragin I.V., Kharitonova N.A., Rychagov S.N., Nuzhdaev A.A., Nuzhdaev I.A. Geochemical features of major and rare-earth element behavior in the Paratunka and Bol'shebannyi hydrothermal systems of Kamchatka. Russian Journal of Pacific Geology, 2016, vol. 10, no. 6, pp. 458-475.

34. Kompanichenko V.N., Poturay V.A. Variations in organic matter composition in waters of the Kuldur thermal field, the Far East of Russia. Tihookeanskaya geologiya, 2015, vol. 34, no. 4, pp. 96-107. In Rus.

35. Poturay V.A. Organic matter in ground- and surface waters in the area of the Annenskii geothermal field, Russian Far East. Geochemistry International, 2017, vol. 55, no. 4, pp. 393-400. In Rus.

36. Poturay V.A. Organic substance in surface waters and groundwters in kuldur deposit of thermal waters, the Far East of Russia. Vestnik KRAUNC. Nauki o Zemle, 2013, no. 1 (21), pp. 169-182. In Rus.

37. Poturay V.A. The organic matter in thermal and surface waters of Tumnin deposit of thermal waters, the Far East of Russia. Bulletin of the Tomsk Polytechnic University, 2014, vol. 324, no. 3, pp. 44-52. In Rus.

38. Kompanichenko V.N., Poturay V.A., Karpov G.A. Organic compounds in thermal water: the Mutnovskii area and the Uzon caldera. Journal of Volcanology and Seismology, 2016, vol. 10, no. 5, pp. $305-319$.

39. Kompanichenko V.N., Poturay V.A., Shlufman K.V. Hydrothermal systems of Kamchatka as the model for prebiotic environment. Origins of Life and Evolution of Biospheres, 2015, vol. 45, no. 1-2, pp. 93-103. DOI: 10.1007/s11084-015-9429-2.

40. Efimova M.V., Kuzyakina T.I. Algobakterialnye soobshhestva plavayushchikh matov Paratunskoy gidrotermalnoy sistemy Kamchatki [Algobacterial communities of floating mats of the Paratunsky hydrothermal system of Kamchatka]. Uspekhi souremennogo estestvoznaniya, 2004, no. 12, pp. 87-88.

41. Chernykh N.A., Kublanov I.V., Prokofeva M.I., Pimenov N.V., Frolov E.N., Lebedinskii A.V., Bonch-Osmolovskaya E.A., Mardanov A.V., Khvashchevskaya A.A., Guseva N.V. Production of organic matter and diversity of the ribulose bisphosphate carboxylase genes in sediments of the Solnechny spring, Uzon caldera, Kamchatka. Microbiology, 2017, vol. 86, no. 5, pp. 666-669. In Rus.

42. Gumerov V.M., Mardanov A.V., Beletsky A.V., Ravin N.V., Bonch-Osmolovskaya E.A. Molecular analysis of microbial diversity in the Zavarzin spring, Uzon caldera, Kamchatka. Microbiolog $y, 2011$, vol. 80, no. 2, pp. 258-265. In Rus.

43. Merkel A.Y., Podosokorskaya 0.A., Sokolova T.G., Bonch-Osmolovskaya E.A. Diversity of methanogenic archaea from the 2012 terrestrial hot spring (Valley of geysers, Kamchatka). Microbiology, 2016, vol. 85, no. 3, pp. 327-336. In Rus.

44. Poturay V.A. Composition and distribution of n-paraffines in nitrogen thermal waters of the Russian Far East. Tikhookeanskaya geologiya, 2017, vol. 36, no. 4, pp. 109-119. In Rus.

45. Kolpakova M.N., Gaskova O.L., Naymushina O.S., Krivonogov S.K. Ebeity lake, Russia: chemical-organic and mineral com- 
position of water and bottom sediments Bulletin of the Tomsk Polytechnic University. Bulletin of the Tomsk Polytechnic University. Geo Assets Engineering, 2018, vol. 329, no. 1, pp. 111-123. In Rus.

46. Kontorovich A.E., Shvartsev S.L., Rasskazov N.M., Zuev V.A., Turov Yu.P. Organic trace contaminants in fresh natural waters from the drainage basins of Tom' and Upper Ob' rivers. Geochemistry International, 2000, vol. 38, no. 5, pp. 480-490.

47. Serebrennikova O.V., Russkikh I.V., Gulaya E.V., Strelnikova E.B., Kadychagov P.B. Hydrocarbons and organic compounds of oxygen in bottom sediments of Altay and Khakassia lakes. Bulletin of the Tomsk Polytechnic University, 2013, vol. 322, no. 1, pp. 130-135. In Rus.
48. Serebrennikova 0.V., Strel'nikova E.B., Russkikh I.V. Composition of organic compounds in bottom sediments of lakes in the taiga and steppe zones in Siberia. Geochemistry International, 2017, vol. 55, no. 12, pp. 1090-1104.

49. Degens Egon T. Geochemistry of sediments: a brief survey. New Jersey, Prentice-Hall Publ., 1965. 342 p.

50. Hunt J.M. Petroleum geochemistry and geology. San Francisco, W.H. Freeman and Company Publ., 1979. 617 p.

Received: 21 February 2018

\section{Information about the authors}

Valery A. Poturay, research associate, Institute for Complex Analysis of Regional Problems FEB RAS. 